Article received on 17 March 2013

Article accepted on 18 March 2013

UDC: $782 ; 78.071 .1$ Вребалов А.

\title{
ASPECTS OF DUALITY IN ALEKSANDRA VREBALOV'S MILEVA
}

\author{
Robert Kirzinger* \\ Boston Symphony Orchestra and \\ Northeastern University
}

\begin{abstract}
Opposition between dynamically balanced elements is a core idea in art. In Aleksandra Vrebalov's 2011 opera Mileva, the title character, Albert Einstein's first wife, is portrayed in a double role that underscores the various conflicts in her life: her status as an aspiring woman physicist in a field (and world) dominated by men, her initially loving but later difficult relationship with Einstein, and the 'otherness' of her Serbian heritage. Vrebalov clarifies and intensifies these dualities through the use of dynamic large-scale architecture and an interpretatively rich musical language incorporating quotations and stylistic allusions.
\end{abstract}

Keywords: contemporary music, opera, Serbian music, Mileva Marić, Albert Einstein, Vida Ognjenović, Aleksandra Vrebalov

\begin{abstract}
Апстракт: Опозиција динамично балансираних елемената је основна идеја у уметности. У опери Милева Александре Вребалов из 2011. године, насловни лик, прва супруга Алберта Ајнштајна, приказана је у двострукој улози која открива разноврсне конфликте у њеном животу: њен статус жене физичара у области (а и у свету) којом доминирају мушкарци, њен с почетка пун љубави, али касније компликовани однос са Ајнштајном, и „другост“ њеног српског наслеђа. Вребалов појашњава и интензивира ове дуалности кроз употребу динамичне архитектонике и интерпретативно богатог музичког језика у који укључује цитате и стилске алузије.
\end{abstract}

* Author contact information: rkirzinger@bso.org 
Кључне речи: савремена музика, опера, српска музика, Милева Марић, Алберт Ајнштајн, Вида Огњеновић, Александра Вребалов

А ита ако оно за чим трагамо заправо скрива музика?! Тон је исто штоо и светла зрак.

[But what if what we are looking for is hidden in the music?! Sound is the same as a ray of light.]

Mileva, Act I, Scene 4

Aleksandra Vrebalov's 2011 opera Mileva absorbs and transforms the gravity of events in the title character's life, folding time and characters in upon themselves through overlapping spirals of music and narrative. With a libretto by Vida Ognjenović based on her 1998 play Mileva Einstein, the opera was commissioned for the $150^{\text {th }}$ anniversary of the Serbian National Theatre and was premiered in Novi Sad and Belgrade in November 2011. The title character is Mileva Marić, best known as Einstein's first wife. Aspiring to become a physicist, a pioneering woman in a field dominated by men, Marić met Einstein at the Zurich Polytechnic in 1896, and they had a daughter out of wedlock in 1902. (That daughter was probably put up for adoption.) They married the following year and had two sons together, but their relationship became difficult; they finally divorced in 1919, although Einstein helped support her and their sons by using his Nobel Prize money to purchase apartment buildings for her in Zurich. Vrebalov's opera treats the time period of Marić's relationship with Einstein and the crisis of personality she experienced in maintaining her individuality in the face of her partner's onrushing destiny.

As drama and as music Mileva makes much of dichotomies, of which several are crucial to its understanding. Social dualities abound: we have already mentioned the central one, that of Marić's status as a woman attempting to enter a field in which her gender is seen as inferior. She is, at first potentially and then actually, a mother, a role no man might experience. She is Serbian, a Slav in Germanic surroundings, having left her family in Vojvodina to gain experience of the broader world. This duality is dramatized in the dual role of Mileva Junior and Mileva Senior, a concept not found in the original play. The latter, sharing the stage with her younger self, experiences her own life with the dubious benefit of hindsight, and for the illumination of the opera's audience. There is conflict between these two characters too; Senior's frustration at Junior's naiveté darkens the drama's atmosphere from the beginning: past and future are simultaneously present, but not precisely reconcilable. The future, embodied in Mileva Senior, is foreseen by her schizophrenic, ambiguously Cassandra-like sister Zorka, whose premonition of Mileva's difficult future is the opera's open- 
ing scene. Of course, there is the Einstein/Marić pair itself as well, the deep and ultimately irreconcilable division between his future greatness and her relative oblivion. The Einstein of the opera, strangely, is a romantic of the first order, a man in love; the work he has done and will do occupies little space in the drama. Here, we have the Einstein who quotes Goethe and Shakespeare, the violin-playing scientist who sees beauty in the order of the universe.

The musical content of Mileva is indivisible from the dramatic matter, manifest in its most basic level by the F-sharp - G-natural duality and instability dominating the melodic character of Zorka's opening scene, as well as her use of both pitched and unpitched vocalization. The timbral and semantic range of this vocal part is one aspect of the complex sonic continuum encompassing noise, musically chaotic textures, dense but harmonically distinct passages, transparent harmonies and lyrical melodies, and simpler tonal-modal tunes. An analogous continuum can be applied to the rhythmic and metrical dimension, ranging from stochastic (random) to mechanical to humanly flexible (i.e. song). By superimposing multiple strands of musical action from different points in these continuums, Vrebalov illuminates the variety of emotional and thematic ideas already incorporated in the libretto.

Fundamentally related to these musical aspects, the opera's narrative 'reality' is threatened and enriched by moments that both exoticize and normalize the context. Although from the perspective of the composer and the opera's first audiences, the Serbian song 'Dunave plavi' ['Oh, Blue Danube'] (Ex. 1) that opens the opera (complete, in the work's original staging, with a band of rustic musicians silhouetted against the pre-dawn horizon) is a 'natural' element, from a traditionally operatic standpoint its presence is an exoticism, like the habanera in Carmen, the ersatz folksong-round 'Old Joe Has Gone Fishing' in Peter Grimes, or indeed the tavern scene of Wozzeck, in spite of the far-flung variety of their foundational musical languages. Vrebalov's use of the accordion among her orchestral instruments - intermittently foregrounded - maintains a tie to this natural/exotic flavour of her and Mileva's homeland. The composer has frequently incorporated such elements in her music; her piece ... hold me neighbor, in this storm..., composed for the Kronos Quartet, features a recording of her grandmother singing the folksong 'Ja posadih jednu ružu belu' ['I Planted a White Rose']. Such elements are never simply grafted on, but richly integrated within the work's larger harmonic, linear, and emotional structures. In Mileva, 'Dunave plavi', having placed us in Serbian emotional space right at the onset of the piece, returns in Scene 5 as a reminder of the character Mileva's duality when her friend Ruzicka, awaiting the start of the New Year's party ushering in the 20th century, begins to sing the old song, now seamlessly present within the opera's narrative. 
'Dunave plavi' is not the only apparent objet trouvé within Vrebalov's larger musical-dramatic form. In each case the object is embedded uniquely and inextricably in the event space of the opera. Such presences also serve as conduits or windows to an alternate universe, an idea already established in the dual role of Mileva. In the third scene, we have one of the opera's explicit examples of thrilling frisson between simultaneous strands of reality. Albert and Mileva (Junior) wait in front of his lodgings for his landlady to awake and let him in. He has forgotten his key for 'the sixth time this semester', as Mileva reminds him - only this reminder is sung by Mileva Senior, seen by the audience but not by Albert, who takes her voice as that of his soon-to-be-sweetheart, whom he interrogates about the meaning of love. The musical cues are also distinct: Vrebalov characterizes Albert with an obbligato accompaniment of virtuosic solo violin from the orchestra pit, binding the character to Eintein's historical self (as Philip Glass had done, quite differently and more ostentatiously, in Einstein on the Beach). The violin phrase is not itself a quotation, but an extension of the baritone's character. Note in Example 2 the pitch correspondence between Albert's A - B-flat phrase ('May I ask you a question?') and the same pitch classes in the lower voice of the violin solo in the following measure. (Albert had also had a solo violin halo at his first appearance, in Scene 2.) Later in the scene, Vrebalov refers more obliquely to Einstein's cultured (and Germanic) heritage with the setting of a textually found object, Rudolf Binding's poem 'Der Tag gehtübermein Gesicht' sung by Mileva Senior as a counterpoint to Mileva Junior's lyrical depiction of love. The scene is multi-dimensionally symbolic here: Mileva Senior's song is about the transience of life, while Mileva Junior speaks of being swept away by love. Senior's song is a slow, meditative one, a sustained current within the light waltz that Junior's aria has become. Thus, we have two concurrent musical time-streams, contrasting, but here reconciled, and two contrasting modes of thought, sung in two languages by two aspects of the same character, reflecting the thematic duality of the piece as a whole. (When Albert joins, making a trio, he tellingly conforms to the waltz character of Mileva Junior's music.)

In Scene 4, Albert and his male colleagues work on a physics problem. Following a percussion-heavy opening that re-established the idea of multiple concurrent tempos, the intellectual rigor of their efforts is symbolized by the scene's being structured as a vast double fugue - again the presence of two tempo-streams, with the voices stepping and out of the current. Mileva Junior's divided self makes tea for the men on the one hand, and sits to add a few notes to their experiment on the other. Albert - balancing Mileva Senior's song of the previous scene - creates a new space for himself, stepping out of the prevailing texture for an aria setting a speech from Act V of Shakespeare's Merchant of 
Venice: 'Look how the floor of heaven'. His colleagues' (other than Mileva's) reaction to this flight of metaphysical fancy - 'Blah blah blah!' - ironically ushers the fast fugue back in, and this, as the colleagues break from their work to play a little music - 'Mozart!' - transforms seamlessly into the overture to Mozart's The Magic Flute. Mozart in this context, despite its familiarity, is just as much an exoticism as 'Dunave plavi'. Following the musically chaotic scene change to the New Year/New Century party of Scene 5, Vrebalov underlines the strangeness of Mozart by having it return quite magically as a recording on a gramophone being played by Ruzicka. (The machine was a very new invention at that time.) The music stops jarringly when Ruzicka takes up the disc to look at it with curiosity before starting to sing 'Dunave plavi', creating two successive exoticisms.

As there are 'found text' and 'found music' passages in Mileva, Vrebalov uses the orchestra to create 'found-sound' events to enliven the theatrical environment. One example is the orchestra's illustration of the shrieking of the postman's bicycle wheels during Zorka's hallucinatory premonition in Scene 1. Another is the interlocked multiple tempos of mechanistic metallic percussion introducing the laboratory scene of Scene 2. The most mysterious of these otherworldly intrusions comes toward the end of Act I, when the disguised Beso sings his dreamlike three-pitch aria 'I buy souls of young scientists'. The regularly pulsed accompaniment of harp, tambourine, and wood blocks evokes the clopping hooves of the horse drawing the scrap-buyer's wagon in the composer's second hometown of Sombor. ${ }^{1}$ The result, experienced by both the characters onstage and the audience, is eerily strange, blending the familiar with the inexplicable. (This precedes an animated Act I finale, a lively ensemble setpiece with chorus with its roots deep in the operatic tradition.)

These richly referential moments, of which the above examples are but a few, intertwine the dramatic and technical-musical elements of Mileva, and all this rests on a sense of architectural balance. Again, one may invoke Wozzeck in its use of large-scale formal structures, although Berg's forms are the preset genres of 'symphony' or 'variation', whereas Vrebalov's, despite the cues of waltz or folksong, are more organically derived. From the widest-angle view, asymmetrical pairings abound. Act II, Scene 1, depicting the parting of Albert and Mileva as she leaves for Serbia to give birth to their illegitimate daughter, is the dark twin of Act I, Scene 3, in which the two declared their love. In this much shorter scene, Mileva Senior is again present, as is the now ironic-sounding waltz, and Mileva Senior sings the setting of another German poem, this time a couplet from Goethe's 'Urworte, orphisch': 'Many a heart goes wandering, but the noblest devote themselves to one'. 
The following scene, back at the Marić family home, naturally echoes much of the music and tone of the first scene in that location, which opened the opera. That scene's orchestration and Zorka's minor-second melodies reappear, but with the presence of the pregnant Mileva things are heard as less suspended as the first scene seemed to be, as tumbling forward inexorably. This is heightened by the scene's transformation directly into the very different Scene 3, the chorus flowing onto the stage with their anthemic, distancing proclamation of Einstein's success before the set has even changed.

Introducing a new musical texture and character in the opera at this point, that scene (Act II, Scene 2) is an important structural pivot, creating an asymmetrical split between one kind of action and mood and another. The proportions of the two largest sections (which do not correspond to the break between the acts) mirror the proportions of individual scenes in their accumulation of energy from onset to emotional/musical peak. For example, the postman's cry of 'Zurich' in Act I, Scene 1; the shift to waltz-tempo and the vocal entrance of Mileva Senior during Junior's aria of Act I, Scene 3 and its echo at the same durationally analogous moment in Act II, Scene 1; and in the finale, where the two Milevas finally converge, all create musical climaxes in the region of their scenes' 'golden sections', the ancient design principle so beloved by Bach, Schubert, and other composers, as well as artists and architects throughout the centuries. This proliferating similarity of structural proportions creates, consciously or otherwise, a sense dynamically organic, vibrant cohesion in the opera's overall shape and flow.

The big second part of Act II - that is, from the second scene onward - illustrates in its pacing and narrative fluidity the increasing instability of Mileva's life. In the blink of an eye, years have passed. In shorter sections with much elision and overlap and great contrast of texture, we learn that Zorka's descended further into madness (which personifies the dissolution of Mileva's world), that Mileva's and Albert's two sons have since been born, that she still mourns her separation from her daughter a decade earlier, and that their marriage has begun to disintegrate. The onstage division of Albert and his male friends on one side and Mileva with her female friends on the other, each backed by a chorus of their gender, seems to obviate the split - a negative to Act I, Scene 2, where Albert and his male colleagues strongly support Mileva's continuation in the physics course - but here, too, Albert's colleagues take Mileva's side. The male chorus sings (in German) the words of a letter Einstein wrote to his wife in about 1914, a heartless denial of an emotional bond between them, essentially lowering Maric to the level of housekeeper and nursemaid. This clashes sharply with the chorus's declamation of Einstein as scientist-hero a few minutes before, and with the recorded quotation of Einstein explaining his famous formula that opens the final scene. 
The final scene leaps forward to Mileva's last years. Again we find a negative image: Mileva Junior is now the semi-passive observer, while Mileva Senior, hospitalized and apparently suffering from delusions foreshadowed by her sister's schizophrenia, occupies the present. Mileva Junior sings further lines from Goethe's 'Urworte' as Senior re-examines the past, addressing her (absent) friend Helena. Finally, the two Milevas engage in a wordless duet accompanied by the angry, intense orchestra in a wrenching lament of frustrated potential - of ambition, of love, of human connection. Vrebalov masterfully uses silence and the contrasting timbres of full orchestra without voices, or solo voices without orchestra, or the combination of the two to add unpredictability and tension to an already very highly strung atmosphere. The two voices finish finally on A-flat and G, a minor second apart (Ex. 3) - etching the same fundamental interval we heard so distinctly at the start of the opera, but now half a step higher. If each scene of the opera is a wave that breaks and flows into the next, this remarkable finale stops frozen at its own peak in searing mid-thought. We, the audience, are left with our own divided selves, simultaneously despairing at the lost potential of a life, while rejoicing in the immensely satisfying artistic experience that is Mileva.

\section{REFERENCES}

1. Personal communication with the composer 
New Sound 40, II/2012

\section{Mileva Ex1 Dunave}

TAMBurasi

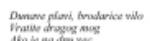

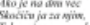

Ponoviti najvise dra pwa, orkestar 20 sekune preklopi sa tamburasio

\section{Mileva Ex2 leitmotif}

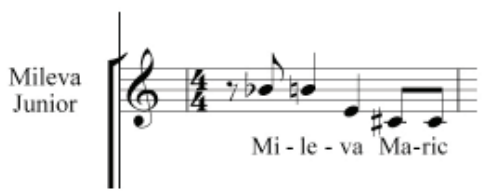

A.E.

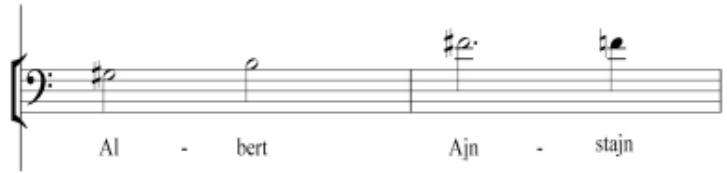

\section{Mileva Ex3 Sc3}

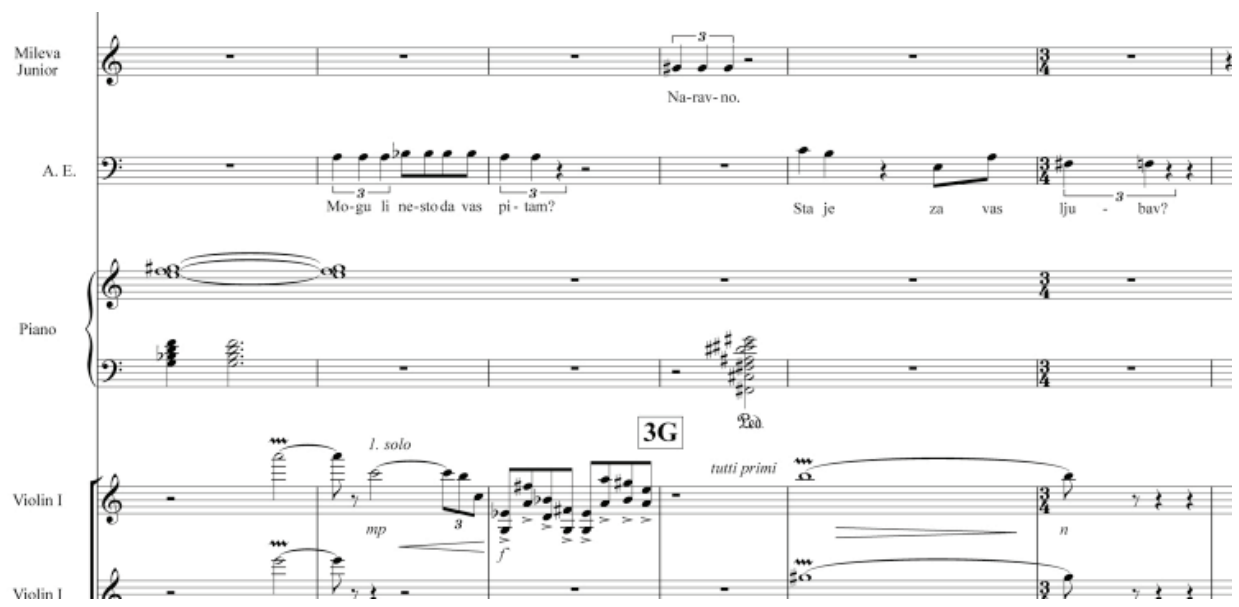




\section{Mileva Ex4 finale}

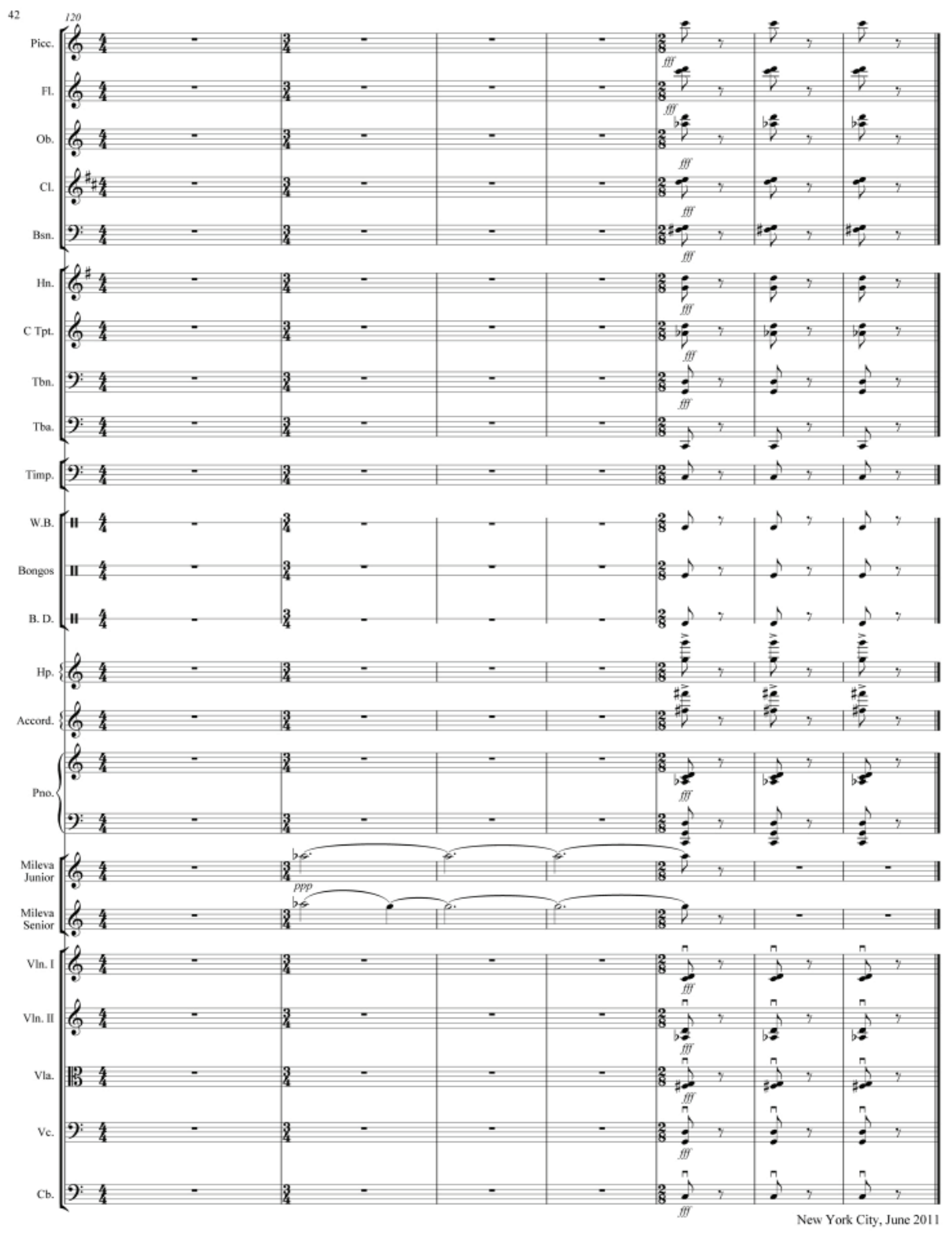

